\title{
Competition in mixed stands of beech and spruce: effects of climate and ozone
}

\author{
S. Rust • A. Roloff
}

Published online: 6 February 2009

(C) Springer-Verlag 2009

The "Growth-Differentiation Balance Theory" assumes a trade-off between parasite defense and increases in growth and competitiveness (Herms and Mattson 1992). Accordingly, increasing resource availability would induce a decrease in secondary metabolites, and hence defense capacity, relative to primary production. Since 1998, about 20 research teams have examined this theory in the interdisciplinary research center "Sonderforschungsbereich 607" (SFB 607), being conducted in Munich and FreisingWeihenstephan (Germany; Matyssek et al. 2005). In this issue, they present results from studies focusing on the effects of ozone and drought stress on beech and spruce competing in mixed stands.

The mature stand as one research object of the reported studies is "Kranzberger Forst", a 55-year-old Norway spruce stand near Freising/Germany with groups of 62year-old beech. From the year 2000 on, a group of beech and spruce trees has been exposed to experimentally enhanced free-air ozone fumigation (Karnosky et al. 2001). Ozone was applied, through a novel methodological approach, via more than 100 PTFE tubes into the stand canopy in such a way that five spruce and five beech trees were exposed to a twice-ambient ozone regime, with ozone levels being restricted to below $150 \mathrm{nl} \mathrm{l}^{-1}$ (Nunn et al. 2002; Werner and Fabian 2002; Karnosky et al. 2007).

The first paper introduces a novel approach to study the hydraulic architecture of coarse roots. Nikolova et al. (2008b, this issue) combined computer tomography, light

S. Rust · A. Roloff $(\square)$

Institut für Forstbotanik und Forstzoologie,

TU Dresden, Postfach 1117, 01735 Tharandt, Germany

e-mail: roloff@forst.tu-dresden.de microscopy, and sap flow measurements in order to anatomically and functionally compare the conductive sapwood area of coarse roots between beech and spruce. Cumulative sapwood lumen area was $12 \%$ of the total coarse root cross-sectional area in both species. Normalized by that parameter, sap flow rate increased with root diameter.

Häberle et al. (2008, this issue) tested a conceptual approach to assess the amount of carbon available for trade-offs between defense and growth. They monitored the variation in levels of nine defense-related metabolite groups within and between four consecutive growing seasons in mature beech and spruce trees. The difference between minimum and maximum metabolite levels was assumed to be dispensable between growth and defenserelated metabolism, ranging between 2 and 5\% of gross primary production.

A set of papers describes the effects of ozone and drought, especially during the extreme summer of 2003. Betz et al. (2008, this issue) investigating the shikimate pathway in the greenhouse and in the field, caution against uncritical comparisons between greenhouse-grown saplings and mature forest trees. Rodenkirchen et al. (2008, this issue) studied the effects of ozone and $\mathrm{CO}_{2}$ on the competitiveness of beech and spruce saplings under standardized phytotron conditions. Ozone stress reduced nutrient efficiencies in beech, suggesting a higher demand for $\mathrm{N}$ and $\mathrm{P}$ in defense at the expense of competitiveness. Elevated $\mathrm{CO}_{2}$ counteracted the effects of ozone. In mature ozonefumigated trees, the extreme summer of 2003 had no effect on the concentrations of $\mathrm{P}$ and $\mathrm{K}$ in the leaves, whereas the control trees had significantly lower levels of these nutrients in 2004 (Göttlein et al. 2008, this issue). Although ozone fumigation reduced absolute tree diameter increment at breast height in spruce, there was no such effect in beech 
(Wipfler et al. 2009, this issue). In beech and spruce, fumigation with ozone affected onset and end of intra-annual diameter increment. In both species, the drought of 2003 reduced autotrophic soil respiration underneath mature trees, much more so in spruce (by 70\%) than in beech (by $50 \%$, Nikolova et al. 2008a, this issue). Although in 2003 fine-root production declined in spruce to less than a fifth of the level during 2002, production remained unchanged in beech.

Seifert and Müller-Starck (2008, this issue) monitored the influence of fructification on growth of individual mature spruce trees, accessing the crown by use of the canopy crane at the site (Häberle et al. 2003). They did not find any reduction in vegetative growth when comparing diameter increment of coning and not-coning trees, neither during the year of fructification nor in the following year.

Rötzer et al. (2008, this issue) present results from a modeling study analyzing the impact of different climate change scenarios on carbon allocation in mixed stands of spruce and beech. In both species, total biomass increment decreased along with increasing severity of the scenarios. In spruce, however, increment decreased more above than belowground, whereas in beech it was the belowground biomass increment that decreased to a greater extent.

Pretzsch and Schütze (2008, this issue) studied the aboveground biomass development in a range of mixed and pure stands of beech and spruce. In both species, individuals grew faster and larger in mixture than in pure stands. The authors explain the effect by facilitation of spruce and reduced intra-specific competition in beech.

The results of these studies lead to the conclusion that increasing levels of stress, such as through climate change, will change the pattern of carbon allocation in mixed stands of beech and spruce and the outcome of competition.

\section{References}

Betz GA, Knappe C, Lapierre C, Welzl G, Langebartels C, Heller W, Sandermann H, Ernst D (2008) Ozone affects shikimate pathway transcripts and monomeric lignin composition in European beech (Fagus sylvatica L.). Eur J For Res (this issue). doi:10.1007/ s10342-008-0216-8

Göttlein A, Rodenkirchen H, Häberle KH, Matyssek R (2008) The extreme summer 2003 triggered nutritional effects in the free air ozone fumigation experiment at the Kranzberger Forst. Eur J For Res (this issue). doi:10.1007/s10342-008-0244-4

Häberle K-H, Reiter IM, Nunn AJ, Gruppe A, Simon U, Gossner M, Werner H, Leuchner M, Heerdt C, Fabian P, Matyssek R (2003) KROCO, Freising, Germany: canopy research in a temperate mixed forest of Southern Germany. In: Basset Y, Horlyck V,
Wright SJ (eds) Studying forest canopies from above: the international canopy crane network. Smithsonian Tropical Research Institute and UNEP, pp 71-78

Häberle KH, Nunn AJ, Reiter IM, Werner H, Heller W, Bahnweg G, Gayler S, Lütz C, Matyssek R (2008) Variation of defence-related metabolites in the foliage of adult beech and spruce-a conceptual approach to approximating traded-off carbon. Eur J For Res (this issue). doi:10.1007/s10342-008-0220-z

Herms DA, Mattson WJ (1992) The dilemma of plants: to grow or defend. Q Rev Biol 67:283-335

Karnosky DF, Gielen B, Ceulemans R, Schlesinger WH, Norby RJ, Oksanen E, Matyssek R, Hendrey GR (2001) FACE systems for studying the impacts of greenhouse gases on Forest Ecosystems. In: Karnosky DF, Scarascia-Mugnozza G, Ceulemans R, Innes JL (eds) The impacts of carbon dioxide and other greenhouse gases on forest ecosystems. CABI Press, pp 297-324

Karnosky DF, Werner H, Holopainen T, Percy K, Oksanen T, Oksanen E, Heerdt C, Fabian P, Nagy J, Heilman W, Cox R, Nelson N, Mytyssek R (2007) Free-air exposure systems to scale up ozone research to mature trees. Plant Biol 9:181-190

Matyssek R, Agerer R, Ernst D, Munch J-C, Osswald W, Pretzsch H, Priesack E, Schnyder H, Treutter D (2005) The plant's capacity in regulating resource demand. Plant Biol 7:560-580

Nikolova PS, Blaschke H, Matyssek R, Pretzsch H, Seifert T (2008a) Combined application of computer tomography and light microscopy for analysis of conductive xylem area in coarse roots of European beech and Norway spruce. Eur J For Res (this issue). doi:10.1007/s10342-008-0211-0

Nikolova PS, Raspe S, Andersen CP, Mainiero R, Blaschke H, Matyssek R, Häberle KH (2008b) Effects of the extreme drought in 2003 on soil respiration in a mixed forest. Eur J For Res (this issue). doi:10.1007/s 10342-008-0218-6

Nunn AJ, Reiter IM, Häberle K-H, Werner H, Langebartels C, Sandermann H, Heerdt C, Fabian P, Matyssek R (2002) "Free-air" ozone canopy fumigation in an old-growth mixed forest: concept and observations in beech. Phyton 42:105-119

Pretzsch H, Schütze G (2008) Transgressive overyielding in mixed compared with pure stands of Norway spruce and European beech in Central Europe: evidence on stand level and explanation on individual tree level. Eur J For Res (this issue). doi:10.1007/ s10342-008-0215-9

Rodenkirchen H, Göttlein A, Kozovits AR, Matyssek R, Grams TEE (2008) Nutrient contents and efficiencies of beech and spruce saplings as influenced by competition and $\mathrm{O}_{3} / \mathrm{CO}_{2}$ regime. Eur J For Res (this issue). doi:10.1007/s10342-008-0221-y

Rötzer T, Seifert T, Pretzsch H (2008) Modelling above and below ground carbon dynamics in a mixed beech and spruce stand influenced by climate. Eur J For Res (this issue). doi:10.1007/s10342008-0213-y

Seifert T, Müller-Starck G (2008) Impacts of fructification on biomass production and correlated genetic effects in Norway spruce (Picea abies [L.] Karst.). Eur J For Res (this issue). doi:10.1007/s10342008-0219-5

Werner H, Fabian P (2002) Free-air fumigation of mature trees. Environ Sci Pollut Res 9:117-121

Wipfler P, Seifert T, Biber P, Pretzsch H (2009) Intra-annual growth reaction of adult Norway spruce (Picea abies [L.] KARST.) and European beech (Fagus sylvatica L.) on free-air ozone fumigation. Eur J For Res (this issue). doi:10.1007/s10342-008-0255-1 